\title{
Cation dynamics and growth morphology of aromatic rice under salt stress
}

\author{
A. Sultana, M. A. Baset Mia* and J. U. Ahmed \\ Department of Crop Botany, Bangabandhu Sheikh Mujibur Rahman Agricultural University, Gazipur, Bangladesh
}

Received: 30 June 2021

Revised: 16 August 2021

Accepted: 23 August 2021

DOI: https://doi.org/10.3329/bjsir.v56i3.55968

\begin{abstract}
Salinity is an abiotic stress which affects plant's growth, morphology and cellular functions, and alters the ionic balance in the cytosol and vacuole in various crops. In the present investigation, salt stress was tested with three rice (Oryza sativa L.) varieties/genotypes viz. Pokkali, Sunduri Samba, and Khasa with three levels of salinity $\left(0,6\right.$, and $\left.9 \mathrm{dSm}^{-1}\right)$. In the investigation, growth, morphology, and ionic status in roots, stem, and leaf were observed under pot culture with three replicates in each treatment. The results of the experiment revealed that salt stress decreased in growth attributes namely, root dry matter, shoot dry matter, total dry matter and root: shoot ratio. Sunduri Samba showed higher values, but Khasa the lowest. Mineral ion content especially the cation in the plant tissue namely $\mathrm{Na}^{+}, \mathrm{K}^{+}, \mathrm{Ca}^{2+}, \mathrm{Mg}^{2+}$ differed significantly due to salt stress as well as the $\mathrm{K}^{+} / \mathrm{Na}^{+}$ratio decreased in root and shoot due to salinity. Sunduri Samba maintained quite higher $\mathrm{K}^{+} / \mathrm{Na}^{+}$than the susceptible genotype. Due to salinity, different growth characteristics and $\mathrm{K}^{+}$concentrations decreased but $\mathrm{Na}^{+}$concentration increased. Here the tolerant genotype Sunduri Samba accumulated higher amounts of $\mathrm{K}^{+}$than the susceptible genotype Khasa and altered the ionic ratios through distribution of $\mathrm{Na}^{+}$ion in shoot.
\end{abstract}

Keywords: Salinity; Aromatic rice; Growth; Morphology; Cation dynamics

\section{Introduction}

Among rice (Oryza sativa L.) aromatic varieties rank most sensitive to salinity. Not only is rice considerably less tolerant to salinity than other species, but salinity affects its growth, morphology and reproductive development quite differently. Photosynthesis inhibition (Sharma et al.,2005), water deficit, ion toxicity associated with excessive $\mathrm{Cl}^{-}$and $\mathrm{Na}^{+}$(Afzal et al., 2008; Patel and Pandey, 2008), interference with nutrition leading to nutrient imbalance (Misra et al., 1997). The $\mathrm{Na}^{+}$ion resulting from salinity is one of the major toxic components for most plants, including the major cereals (Tester and Davenport, 2003). Because $\mathrm{Na}^{+}$is chemically similar to $\mathrm{K}^{+}$, a certain amount of its harmfulness is due to interference at some level with the transport and cytoplasmic functions of $\mathrm{K}^{+}$. On the other hand, uptake of $\mathrm{Na}^{+}$badly affects the cellular $\mathrm{K}^{+} / \mathrm{Na}^{+}$ratio and may lead to cell death.
Physiologically, NaCl-based salinity has several implications on plant growth and development which enforces an initial water deficit that results from the relatively high solute concentrations in the soil. This phenomenon causes ion-specific stresses resulting from altered $\mathrm{K}^{+} / \mathrm{Na}^{+}$ratio and builds up detrimental levels of cellular $\mathrm{Na}^{+}$and $\mathrm{Cl}^{-}$concentrations finally the ion toxicity (Gupta and Huang, 2014). Growth and survival of vascular plants at high salinity depends on adaptation to both low water potentials and high $\mathrm{Na}^{+}$concentrations, as high salinity in the external solution of plant cells produces a variety of negative consequences. Considering $\mathrm{NaCl}$ as the primary inflictor of salinity, the penalty of a high extracellular $\mathrm{NaCl}$ concentration on plant is obvious (Parida and Das, 2005). Cellular ionic imbalance generated from excess $\mathrm{Na}^{+}$and $\mathrm{Cl}^{-}$ions affect life processes negatively. 
$\mathrm{Na}^{+}$enters cell efficiently through $\mathrm{K}^{+}$transport channels, effectively replaces monovalent of cations like $\mathrm{K}^{+}$as cofactors of several enzymatic processes, and in doing so inhibits such enzyme activities. Therefore, plant survival and growth depend on adaptations to re-establish ionic homeostasis (Sengupta and Majumder, 2010).

High salinity results in increased cytosolic $\mathrm{Ca}^{2+}$ that is transported from the apoplast and intracellular compartments. The resultant transient $\mathrm{Ca}^{2+}$ increase potentiates stress signal transduction and leads to salt adaptation. A prolonged elevated $\mathrm{Ca}^{2+}$ level may, however, also pose a stress; if so, reestablishment of $\mathrm{Ca}^{2+}$ homeostasis is a requisite (Hasegawa et al., 2000). $\mathrm{Ca}^{2+}$ can facilitate higher $\mathrm{K}^{+} / \mathrm{Na}^{+}$selectivity, and interestingly, external $\mathrm{Ca}^{2+}$ can suppress the $\mathrm{K}^{+}$acquisition deficiency of salt overly sensitive (SOS). The transport systems involved in $\mathrm{K}^{+}$acquisition by roots and loading to the xylem have been summarized recently (Maathuis et al., 1997). $\mathrm{Na}^{+}$efflux across the plasma membrane and compartmentalization into vacuoles or pre-vacuoles is mediated presumably by $\mathrm{Na}^{+} / \mathrm{H}^{+}$antiporters, regardless of whether or not the membrane potential is inside positive or negative.

The role of $\mathrm{Mg}^{2+}$ is unclear under salt stress, since responses have been variable in vitro. For instance, it increases in rice callus (Ahmad et al., 2009), decreases in soybean callus (Liu and Staden, 2001), and is unaffected in callus of Sonneratia alba Sm. (Yasumoto et al., 1999).

Net $\mathrm{Na}^{+}$fluxes in anatomically distinct root zones of rice seedlings and analyzed parts of individual roots showing different $\mathrm{Na}^{+}$uptake where the anatomically distinct root zones contributed differently to the overall uptake of $\mathrm{Na}^{+}$(Zhou et al., 2011). The average $\mathrm{Na}^{+}$uptake in root zones in which Casparian strip of the endo-and exo-dermis were interrupted by initiating lateral root primordia was significantly greater than that at the root apex, where Casparian strip were not yet formed, or in the region where endo and exodermis with Casparian strip were not well developed. The major role of this specialized structure is to block the nonselective apoplastic bypass flow of ions and water through the cortex into the stele of the root (Yadavet al., 1996). However, Casparian strip of the endo-and exo-dermis are not a perfect barrier to apoplastic fluxes of water, dissolved solutes and ions, as well as apoplastic tracer dyes.

Due to several complexities, the mechanisms of genetic control of salt tolerance in plants have not yet fully understood. In fact, there are several genes controlling salinity tolerance in the different species whose effect interacts strongly with environmental conditions. Thus, genetic variation can only be demonstrated indirectly, by measuring the responses of different genotypes. Probably the most suitable response to measure is growth or yield, especially at moderate salinities (Carillo et al., 2011). Salt tolerance, in fact, can be usually assessed as the percent biomass production in saline versus control conditions over a prolonged period of time (this usually correlates with yield) or in terms of survival, which is quite appropriate for perennial species (Munns, 2002).Therefore, the present experiment was conducted to investigate the effect of salinity on growth, morphology and cation dynamic of aromatic fine rice varieties/genotypes under salt stress condition.

\section{Materials and methods}

This experiment was conducted at the shade-house of the department of Crop Botany, Bangabandhu Sheikh Mujibur Rahman Agricultural University (BSMRAU), Gazipur, Bangladesh. Three rice genotypes viz. Sunduri Samba, tolerant check Pokkali and susceptible Khasa were used with three levels of salinity $\left(0,6,9 \mathrm{dSm}^{-1}\right)$ where salt was applied in three equal splits at two days interval.Plastic pots containing about $8 \mathrm{~kg}$ soils were used in this experiment. Fertilizers namely urea, triple super phosphate (TSP) and muriate of potash (MoP) were used for $\mathrm{N}, \mathrm{P}$ and $\mathrm{K}$ at the rate of $0.19,0.06$ and $0.07 \mathrm{~g} \mathrm{~kg}^{-1}$ soil,respectively. The MoP and TSP were applied as basal doses before transplanting where urea was applied at topdressing in three equal splits. The experiment was laid out in two factorials completely randomized design(CRD) with three replications, where factor: 1 genotype-3, factor2: salinity level-3 $\left(0,6,9 \mathrm{dSm}^{-1}\right)$. The three genotypes in combination with two salinity levels were randomly assigned in 27 pots. After 14 days of salt deposition different physiological parameters were taken from the fresh leaf samples. At final harvest, roots were carefully cleaned with running tap water and finally washed with distilled water. Rice plants were separated into roots, shoots and seeds and rinsed repeatedly with tap water and finally with distilled water and thereafter dried in an electrical oven (Froilabo, France) at $71^{\circ} \mathrm{C}$ to obtain a constant weight. The mean root dry weight pot $^{-1}$ was calculated for each treatment. Shoot dry weight was calculated from the summation of leaf, stem and panicle dry weight. The total dry matter (TDM) was calculated from the summation of root and shoot dry matter.

For estimation of $\mathrm{Na}^{+}, \mathrm{K}^{+}, \mathrm{Ca}^{2+}$ and $\mathrm{Mg}^{2+}$, oven-dried plant samples were ground in a Wiley Hammaer Mill (Willy PULVERIZB, Yoshida Seisakusho Co.Ltd), passed through 40 mesh screens, mixed well and stored in plastic vials.For acid digestion, oven-dried ground plant tissues $(0.5 \mathrm{~g})$ and $5 \mathrm{ml}$ of di-acid $\left(\mathrm{HNO}_{3}\right.$ and $\left.\mathrm{HClO}_{4}\right)$ mixture were taken in a 
digestion tube and left for $20 \mathrm{~min}$ then transferred to a digestion block and continued heating at $100^{\circ} \mathrm{C}$ and left to digest until yellowish color of the solution turned to whitish color. Then the tubes were removed from heating chamber and left it to cool to room temperature. About $40 \mathrm{ml}$ of de-ionized water was carefully added to the digestion tubes and the contents filtered through Whatman no. 40 filter paper into a $100 \mathrm{ml}$ volumetric flask and the volume was made up to the mark with de-ionized water. Content of $\mathrm{Na}^{+}, \mathrm{K}^{+}, \mathrm{Ca}^{2+}$, $\mathrm{Mg}^{2+}$ were determined by Atomic Absorption Spectrophotometer (Model-170-30, Hitachi, Japan).

\section{Results and discussion}

The shoot dry weight (SDW) showed serious reduction with the increase of salinity however Pokkali recorded the tolerance reflecting the highest values in all the salinity levels (Table I). However, other two genotypes did not show any significant difference both at 6 and $9 \mathrm{dSm}^{-1}$.

Similarly, root dry weight (RDW) reduced the increment of salt stress both the genotypes Sunduri Samba and Khasa did not show significant difference both at 6 and 9 $\mathrm{dSm}^{-1}$ (Table I).

There was a similarity among SWD, RWD and total dry matter (TDM) where rise of salt stress declines the TDM (Table II). However, the genotypes Sunduri Samba and Khasa did not show significant difference both at 6 and 9 $\mathrm{dSm}^{-1}$. But the genotype Pokkali maintained the highest scores among all the salinity levels.
It is apparent that salt stress resulted in marked change in root: shoot ratio (Table II). Saline conditions significantly altered the tissue concentration of different ion content both in shoot and root (Fig. 1). There was a sharp decrease in $\mathrm{K}^{+}$content as the salt stress increased. Here, the tolerant genotype Sunduri Samba had quite a large $\% \mathrm{~K}^{+}$value at 6 $\mathrm{dSm}^{-1}$ than the susceptible genotype Khasa. However, at 9 $\mathrm{dSm}^{-1}$ both the tolerant $(0.51)$ and susceptible $(0.42)$ genotype showed little difference. Other than shoot, Sunduri Samba had higher $\% \mathrm{~K}^{+}$value than the susceptible genotype Khasa both at $6 \mathrm{dSm}^{-1}$ and $9 \mathrm{dSm}^{-1}$. One thing is clear that shoot maintained a higher concentration of $\mathrm{K}^{+}$ than root.

Salinity caused dramatic increases in both root and shoot $\mathrm{Na}^{+}$ content. Unlike the $\mathrm{K}$ concentration Pokkali had the lowest value of $\mathrm{Na}$ concentration both at 6 and $9 \mathrm{dSm}^{-1}$ (Fig. 2). However, the tolerant genotype Sunduri Samba and susceptible Khasa had statistically similar $\% \mathrm{Na}^{+}$value both at 6 and $9 \mathrm{dSm}^{-1}$.

In root, a different type of trend was observed, where Pokkali and Khasa had the highest $\% \mathrm{Na}^{+}$value both at 6 and $9 \mathrm{dSm}^{-1}$ which were statistically non-significant. Moreover, Sunduri Samba maintained the lowest $\% \mathrm{Na}^{+}$ value both at 6 and $9 \mathrm{dSm}^{-1}$.

Hussain et al. (2003) observed that $\mathrm{Na}^{+}$concentration increased in root and shoot of rice due to increase of its concentration in root medium and it significantly increased the $\mathrm{Ca}^{2+}$ concentration in root and tissues at higher salinity.

Table I. Effects of different level of salt stress on shoot and root dry weight of three selected rice genotypes

\begin{tabular}{|c|c|c|c|c|c|c|}
\hline \multirow{3}{*}{$\begin{array}{c}\text { Treatment/ } \\
\text { genotype }\end{array}$} & \multicolumn{3}{|c|}{ Salinity levels $\left(\mathrm{dSm}^{-1}\right)$} & \multicolumn{3}{|c|}{ Salinity levels $\left(\mathrm{dSm}^{-1}\right)$} \\
\hline & 0 & 6 & 9 & 0 & 6 & 9 \\
\hline & \multicolumn{3}{|c|}{ Shoot dry weight $\left(\mathrm{g} \mathrm{pot}^{-1}\right)$} & \multicolumn{3}{|c|}{ Root dry weight $\left(\mathrm{g} \mathrm{pot}^{-1}\right)$} \\
\hline Sunduri Samba & $12.07 \mathrm{a}$ & $2.33 \mathrm{~b}$ & $0.93 \mathrm{~b}$ & $3.13 \mathrm{~b}$ & $0.42 \mathrm{~b}$ & $0.15 \mathrm{~b}$ \\
\hline Khasa & $11.80 \mathrm{a}$ & $1.87 \mathrm{~b}$ & $0.63 \mathrm{~b}$ & $4.64 \mathrm{a}$ & $0.39 \mathrm{~b}$ & $0.13 \mathrm{~b}$ \\
\hline Pokkali & $13.03 \mathrm{a}$ & $5.63 \mathrm{a}$ & $4.03 \mathrm{a}$ & $4.91 \mathrm{a}$ & $1.41 \mathrm{a}$ & $0.39 \mathrm{a}$ \\
\hline LSD & 2.04 & 0.80 & 0.58 & 1.08 & 0.29 & 0.06 \\
\hline CV (\%) & 8.30 & 12.20 & 15.46 & 12.77 & 19.47 & 11.41 \\
\hline
\end{tabular}

Values having same letter(s) in a column do not differ significantly at $5 \%$ level of significance by DMRT 
Table II. Effects of different level of salt stress on total dry matter and root: shoot ratio of three selected rice genotypes

\begin{tabular}{cccccccc}
\hline $\begin{array}{c}\text { Treatment/ } \\
\text { genotype }\end{array}$ & \multicolumn{3}{c}{ Salinity levels $\left(\mathrm{dSm}^{-1}\right)$} & \multicolumn{5}{c}{ Salinity levels $\left(\mathrm{dSm}^{-1}\right)$} \\
\hline & 0 & 6 & 9 & 0 & 6 & 9 \\
\cline { 2 - 8 } & \multicolumn{2}{c}{ Total dry matter $(\mathrm{TDM})\left(\mathrm{g} \mathrm{pot}^{-1}\right)$} & \multicolumn{5}{c}{ Root: shoot ratio } \\
\hline Sunduri Samba & $14.86 \mathrm{~b}$ & $2.75 \mathrm{~b}$ & $1.09 \mathrm{~b}$ & $0.26 \mathrm{~b}$ & $0.18 \mathrm{~b}$ & $0.16 \mathrm{a}$ \\
Khasa & $16.77 \mathrm{a}$ & $2.25 \mathrm{~b}$ & $0.76 \mathrm{~b}$ & $0.38 \mathrm{a}$ & $0.17 \mathrm{~b}$ & $0.13 \mathrm{a}$ \\
Pokkali & $17.61 \mathrm{a}$ & $7.05 \mathrm{a}$ & $4.42 \mathrm{a}$ & $0.38 \mathrm{a}$ & $0.26 \mathrm{a}$ & $0.18 \mathrm{a}$ \\
\hline LSD & 1.764 & 1.03 & 0.46 & 0.06 & 0.02 & 0.06 \\
CV $(\%)$ & 5.38 & 12.78 & 10.91 & 7.33 & 13.26 & 16.82 \\
\hline
\end{tabular}

Values having same letter(s) in a column do not differ significantly at 5\% level of significance by DMRT

Table III. Effects of different levels of salt stress on $\mathrm{Ca}$ and $\mathrm{Mg}$ ion content in the shoot of three selected rice genotypes

\begin{tabular}{ccccccc}
\hline $\begin{array}{c}\text { Treatment/ } \\
\text { genotype }\end{array}$ & \multicolumn{3}{c}{ Salinity levels $\left(\mathrm{dSm}^{-1}\right)$} & \multicolumn{5}{c}{ Salinity levels $\left(\mathrm{dSm}^{-1}\right)$} \\
& 0 & 6 & 9 & 0 & 6 & 9 \\
\cline { 2 - 7 } & \multicolumn{3}{c}{$\% \mathrm{Ca}$} & $0.37 \mathrm{a}$ & $0.48 \mathrm{a}$ \\
\hline $\begin{array}{c}\text { Sunduri Samba } \\
\text { Khasa }\end{array}$ & $0.38 \mathrm{a}$ & $0.66 \mathrm{a}$ & $0.74 \mathrm{~b}$ & $0.28 \mathrm{a}$ & $0.37 \mathrm{a}$ & $0.47 \mathrm{a}$ \\
Pokkali & $0.39 \mathrm{a}$ & $0.59 \mathrm{ab}$ & $0.68 \mathrm{~b}$ & $0.28 \mathrm{a}$ & $0.35 \mathrm{a}$ & $0.49 \mathrm{a}$ \\
\hline LSD & 0.06 & $0.52 \mathrm{~b}$ & $0.82 \mathrm{a}$ & $0.29 \mathrm{a}$ & $0.38 \mathrm{a}$ & 0.06 \\
CV (\%) & 7.75 & 0.09 & 0.06 & 0.06 & 0.06 & 7.96 \\
\hline
\end{tabular}

Values having same letter(s) in a column do not differ significantly at 5\% level of significance by DMRT

It is apparent that $\mathrm{K} / \mathrm{Na}$ ratio decreased with the increase of salinity and in that case, the shoot and root showed quiet similar type of results (Figure 3). Both in shoot and root, Pokkali had the highest values than the other genotypes both at 6 and $9 \mathrm{dSm}^{-1}$. On the other hand, in shoot, the tolerant variety Sunduri Samba had the higher value than Khasa at $6 \mathrm{dSm}^{-1}$ level of salinity. However, at $9 \mathrm{dSm}^{-1}$ both the genotypes showed similar type of results. In root, Sunduri Samba had the higher value than Khasa both at $6 \mathrm{dSm}^{-1}$ and $9 \mathrm{dSm}^{-1}$.

It is apparent from Table (III,IV) that there was a significant variation in the relative value on $\mathrm{Ca}^{2+}$ content in shoots and roots of different rice genotypes due to salinity. However, shoot maintained the higher value than root. Both in shoot and root $\% \mathrm{Ca}^{2+}$ content increased with the increment of salinity level (Table III, IV).
In this experiment, as the $\mathrm{NaCl}$ stress increased the $\% \mathrm{Mg}^{2+}$ concentration increased in shoot, whereas in root there was a decreasing trend (Table III, IV). Here both in root and shoot, there was not any genotypic variations among all three genotypes both at 6 and $9 \mathrm{dSm}^{-1}$.

The key feature of the research indicates that the genotype Sunduri Samba maintained higher $\mathrm{K}^{+} / \mathrm{Na}^{+}$ratio than the genotype Khasa. Again, in other measuring characteristics it got a convincing figure to tag it as a tolerant genotype. As the salt stress increases the morphological characteristics showed reduced values. In that case, the tolerant genotype Pokkali had higher values than the other genotypes. However, Sunduri Samba showed quiet higher values than Khasa. It is reported that shoot growth is more sensitive than root growth to salt- induced osmotic stress (Ehlting et al., 2007) probably because a reduction in the leaf area development relative to root growth would decrease the 
Table IV. Effects of different levels of salt stress on Ca and Mg ion content in the root of three selected rice genotypes

\begin{tabular}{ccccccc}
\hline $\begin{array}{c}\text { Treatment/ } \\
\text { genotype }\end{array}$ & \multicolumn{3}{c}{ Salinity level $\left(\mathrm{dSm}^{-1}\right)$} & \multicolumn{5}{c}{ Salinity level $\left(\mathrm{dSm}^{-1}\right)$} \\
\hline & 0 & 6 & 9 & 0 & 6 & 9 \\
\cline { 2 - 7 } & $0.26 \mathrm{a}$ & $0.39 \mathrm{a}$ & $0.48 \mathrm{a}$ & $0.32 \mathrm{a}$ & $0.23 \mathrm{a}$ & $0.13 \mathrm{a}$ \\
\hline Sunduri Samba & $0.24 \mathrm{a}$ & $0.34 \mathrm{a}$ & $0.45 \mathrm{ab}$ & $0.33 \mathrm{a}$ & $0.24 \mathrm{a}$ & $0.16 \mathrm{a}$ \\
Khasa & 0.24 & $0.41 \mathrm{~b}$ & $0.37 \mathrm{a}$ & $0.22 \mathrm{a}$ & $0.18 \mathrm{a}$ \\
Pokkali & $0.25 \mathrm{a}$ & $0.33 \mathrm{a}$ & 0.41 & 0.06 & 0.06 \\
LSD & 0.06 & 0.06 & 0.06 & 0.06 & 9.80 & 14.77 \\
CV (\%) & 10.98 & 7.71 & 8.38 & 8.21 & \\
\hline
\end{tabular}

Values having same letter(s) in a column do not differ significantly at 5\% level of significance by DMRT

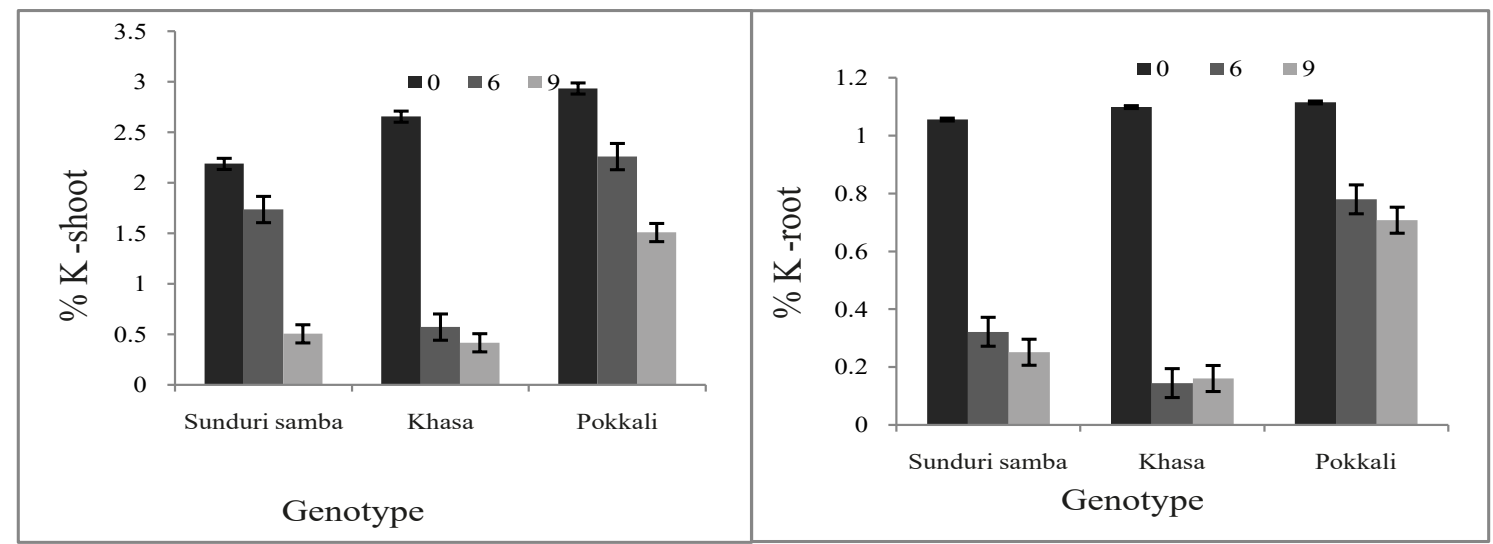

Fig. 1. Effects of salt stress on $\mathrm{K}^{+}$content of shoots and roots of three different rice plants. Level of salt stress $0,6,9 \mathrm{dSm}^{-1}$
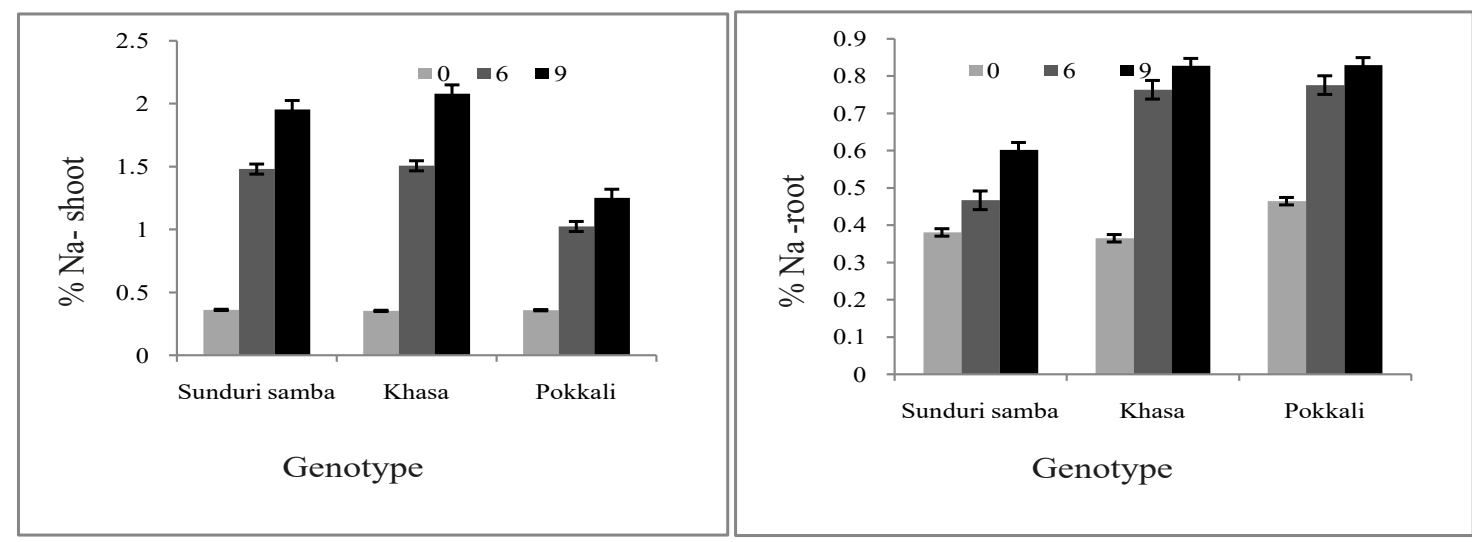

Fig. 2. Effects of salt stress on $\mathrm{Na}^{+}$content of shoots and roots of three different rice plants. Level of salt stress $0,6,9 \mathrm{dSm}^{-1}$ 


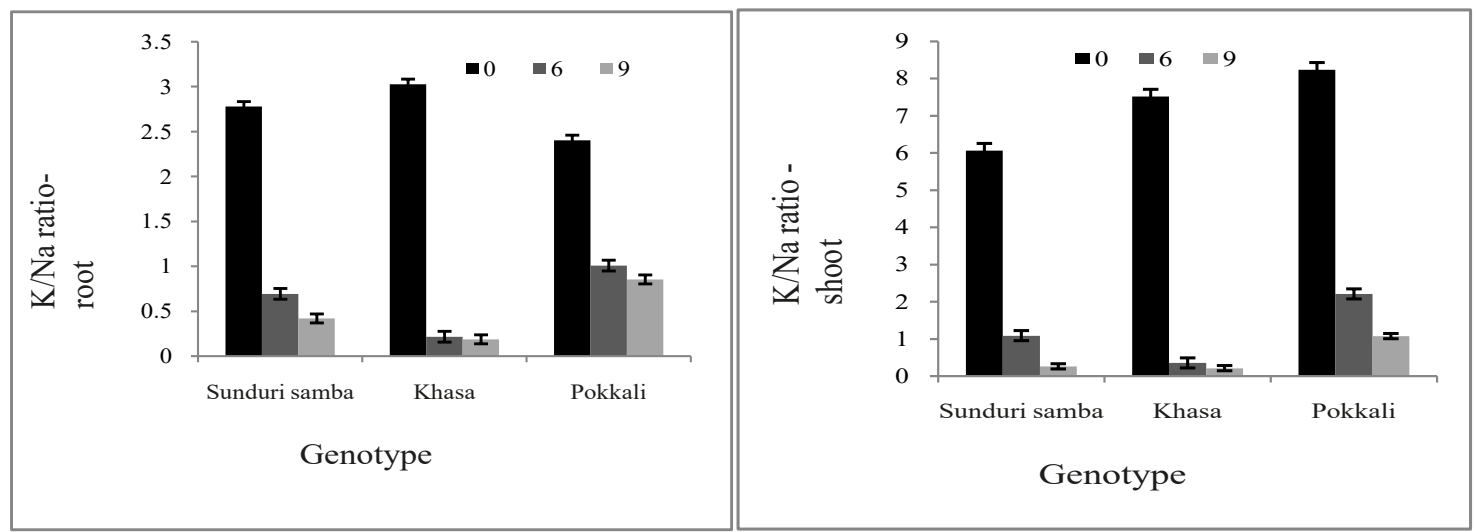

Fig. 3. Effect of salt stress on $\mathrm{K}^{+} / \mathrm{Na}^{+}$ratio of shoots and roots of three different rice plants. Level of salt stress $0,6,9 \mathrm{dSm}^{-1}$

water use by the plant, thus allowing it to conserve soil moisture and prevent salt concentration in the soil (Munns and Tester, 2008). The reduction of root growth by $\mathrm{NaCl}$ was closely correlated with the increase in ionically bound peroxidase activity in roots of $\mathrm{NaCl}$-stressed rice seedlings (Lin and Kao, 2001). Asch et al. (2000) reported that the growth reductions were attributed to unknown mechanisms and the apparent losses might be due to several factors, such as root decomposition and exudation, and energy consuming processes such as osmoregulation and interaction of $\mathrm{Na}$ and $\mathrm{K}$ from the transpiration stream and subsequent storage in leaf sheaths. The striking feature of this experiment was to measure different ion concentration against different salt stress. Here we demonstrated that all the genotypes got reduced amount of $\mathrm{K}^{+}$ion contentas the salinity level increased. In normal conditions, with cytosolic $\mathrm{K}^{+}$being around $150 \mathrm{mM}$ and cytosolic $\mathrm{K}^{+} / \mathrm{Na}^{+}$in a much lower range, this ratio is rather high $(\sim 100)$, enabling normal cell metabolism which includes cell osmoregulation, turgor maintenance, stomatal function, activation of enzymes, protein synthesis, oxidative metabolism and, in particular, photosynthesis (Marschner, 1995; Shabala, 2003). In terms of genotypic difference, the $\mathrm{K}^{+}$results appear to be much more sensitive indicators of salt tolerance than $\mathrm{Na}^{+}$. It is not surprising therefore that the $\mathrm{K}^{+} / \mathrm{Na}^{+}$ratio in plant tissues has often been suggested as a potential screening tool for plant breeders (Chen et al., 2005). On the other hand, the $\mathrm{K}^{+}$ accumulation in roots and shoots was slightly inhibited in response to salinity (Trinchant et al., 2004).

The second pertinent point of this experiment was to measure $\mathrm{Na}^{+}$ion contentincrement with the increase of salinity.In terms of $\mathrm{Na}^{+}$content the scenario was indifferent than the $\mathrm{K}^{+}$ content. Here $\mathrm{Na}^{+}$content increased with the increase of salinity and the genotype Khasa had the highest amount other than two genotypes which is not acceptable to select as a tolerant genotype. On the other hand, Sunduri Samba showed a bit agreeable value here. Salinity treatment caused immediate changes in net $\mathrm{Na}^{+}, \mathrm{K}^{+}, \mathrm{H}^{+}$and $\mathrm{Ca}^{2+}$ fluxes from barley root surface (Chen et al., 2005). They also stated that, salt stress significantly lowered $\mathrm{K}^{+}$content in both roots and shoots of all the cultivars studied, but the inhibitory effects of $\mathrm{NaCl}$ were much less in the tolerant cultivars than in the susceptible ones. Orcutt and Nilsen (2000) stated that higher amount of $\mathrm{Na}^{+}$in root than shoot was the result of the process of re-absorption. Velu and Srivastava (2000) found that $\mathrm{Na}^{+}$ content increased $\mathrm{K}^{+}$content decreased in plant tissue irrespective of varieties at all stages of growth. They also found that the sensitive variety had high $\mathrm{Na}^{+}$content coupled with low $\mathrm{K}^{+}$content compared to moderately tolerant and tolerant variety. Increasing concentrations of $\mathrm{NaCl}$ from 50-150 mM progressively decreased root growth and increased $\mathrm{Na}^{+}$(Lin and Kao, 2001). Bal and Chattopadhyay (1989) observed that salt tolerant cultivar had greater $\mathrm{Na}^{+}$ retention in roots and shoots. Salt tolerant cultivars had lower $\mathrm{Na}^{+}$and higher $\mathrm{K}^{+}$contents due to salinity (Won et al., 1992).

One of the key features of plant to salt tolerance is the ability of plant cells to maintain optimal $\mathrm{K}^{+} / \mathrm{Na}^{+}$ratio in the cytosol.Under salinity, however, the $\mathrm{K}^{+} / \mathrm{Na}^{+}$ratio falls dramatically. This occurs as a result of both excessive $\mathrm{Na}^{+}$ accumulation in the cytosol and enhanced $\mathrm{K}^{+}$leakage from the cell, the latter resulting from $\mathrm{NaCl}$-induced membrane depolarization under saline conditions. In that case, the genotype Pokkali and Sunduri Samba showed higher value than the susceptible genotype Khasa. $\mathrm{Na}^{+} / \mathrm{K}^{+}$ratio may serve as an indicator of crop tolerance to stress as the increase of $\mathrm{Na}^{+}$in salt tolerant species is generally associated with a decrease in $\mathrm{K}^{+}$(Greenway and Munns, 1980). They also said that with the increase of $\mathrm{NaCl}$ in the medium the $\mathrm{Na}^{+} / \mathrm{K}^{+}$ratio 
increased in stem and leaf and root up to $120 \mathrm{mM} \mathrm{NaCl}$ and decreased back again at $160 \mathrm{mM} \mathrm{NaCl}$.

Ottow et al. (2005) found that the vacuolar $\mathrm{Na}^{+}$concentrations increased only after prolonged exposure and after cytosolic increases had occurred. However, in both apoplast and vacuole, accumulation of $\mathrm{Na}^{+}$resulted in decreases in $\mathrm{Ca}^{2+}$. This might imply that $\mathrm{Ca}^{2+}$ is important in mediating salt adaptation and that this process occurs independently of osmotic stress or the necessity of acute defense against $\mathrm{Na}^{+}$ toxicity. However, in our study, we administered the $\mathrm{Ca}^{2+}$ content increase with the increase of salinity. But the genotypic variation for $\mathrm{Ca}^{2+}$ content was no significant. In our study the increase of $\mathrm{Mg}^{2+}$ content was observed with the increase of salt stress. It is reported that the accumulation of $\mathrm{Mg}^{2+}$ in the leaf of the plant was helpful to maintain osmoregulation to protect the plant cells from osmotic shock caused by salinity (Greenway and Munns, 1980).

\section{Conclusion}

Due to salinity $\mathrm{Na}^{+}$concentration increased with the decrease in $\mathrm{K}^{+}$concentrations. Again $\mathrm{K}^{+} / \mathrm{Na}^{+}$ratio decreased due to salinity. In that case, tolerant genotype showed lower $\mathrm{Na}^{+}$concentration, higher $\mathrm{K}^{+}$ concentrations and higher $\mathrm{K}^{+} / \mathrm{Na}^{+}$. Concentration of $\mathrm{Ca}^{2+}$, $\mathrm{Mg}^{2+}$ in shoot increased with the increase of salinity. In shoot, Sunduri Samba had the highest $\mathrm{Ca}^{2+}$ value and Pokkali had the lowest value at $6 \mathrm{dSm}^{-1}$. On the other hand, at $9 \mathrm{dSm}^{-1}$ Pokkali had the highest value and Khasa had the lowest value. In root, at $6 \mathrm{dSm}^{-1}$ all three genotypes showed statistically similar values. But at 9 $\mathrm{dSm}^{-1}$ Sunduri Samba had the highest value and Pokkali had the lowest value. In case of $\mathrm{Mg}^{2+}$ both in root and shoot, there was not any genotypic variations among all three genotypes both at 6 and $9 \mathrm{dSm}^{-1}$. But there was significant increase in $\mathrm{Ca}^{2+} \mathrm{Mg}^{2+}$ content both in root and shoot as the salinity increases.

The tolerant genotype (Sunduri Samba, Pokkali) maintained higher $\mathrm{K}^{+}$ion concentration, $\mathrm{K}^{+} / \mathrm{Na}^{+}$ratio and lower $\mathrm{Na}^{+}$ion concentration. Therefore, it seems that tolerant genotypes could adapt better in salt stress than the susceptible one.Considering the changes in different ion concentration and $\mathrm{K}^{+} / \mathrm{Na}^{+}$ratio Sunduri Samba can be used for further experimentation in salt tolerance mechanism.

\section{References}

Afzal I, Rauf S, Basra SMA and Murtaza G (2008), Halopriming improves vigor, metabolism of reserves and ionic contents in wheat seedlings under salt stress, PlantSoil and Environment 54: 382-388.
Ahmad MSA, Javed F, Javed S and Alvi AK (2009), Relationship between callus growth and mineral nutrients uptake in salt-stressed Indica rice callus, Journal of Plant Nutrition 32: 382-394.

Asch F, Dingkuhn M,Dörffling K and Miezan K (2000), Leaf $\mathrm{K} / \mathrm{Na}$ ratio predicts salinity induced yield loss in irrigated rice,Euphytica 113: 109-118.

Bal AR and Chattopaddhyay NC (1989), Effect of different salts on mineral uptake of tolerant and susceptible rice (Oryza sativa L.) cultivars,Journalof Indian Society of Coastal Agricultural Research 7(1): 1-11.

Carillo P, Annunziata MG, Pontecorvo G, Fuggi A and Woodrow P (2011), Salinity stress and salt tolerance, abiotic stress in plants - Mechanisms and adaptations, Ed. Shanker A, ISBN: 978-953-307-394-1. pp 21-38.

Chen Z, Newman I, Zhou M, Mendham N, Zhang G and Shabala $S$ (2005), Screening plants for salt tolerance by measuring $\mathrm{K}^{+}$flux: a case study for barley, Plant Cell and Environment 28: 1230-1246.

Ehlting B, Dluzniewska P, Dietrich H, Selle A, Teuber M, Hänsch R, Nehls U, Polle A, Schnitzler JP, Rennenberg H and Gessler A (2007), Interaction of nitrogen nutrition and salinity in Grey poplar (Populus tremula $¥$ alba),Plant Cell and Environment 30: 796-811.

Greenway H and Munns R (1980), Mechanisms of salt tolerance in nonhalophytes, Annual Review of Plant Physiology 31: 149-190.

Gupta B and Huang B (2014), Mechanism of salinity tolerance in plants: Physiological, biochemical, and molecular characterization, International Journal of Genomics 2014: 18

Hasegawa PM, Bressan RA, Zhu JK and Bohnert HJ (2000), Plant cellular and molecular responses to high salinity. Annual Review of Plant Physiology 51: 463-499.

Hussain N, Ali A, Khan AG, Rahman OU and Tahir M (2003), Selectivity of ions absorption as mechanism of salt tolerance in rice (variety Shaheen Bashmoti),Asian Journal of Plant Science 2(5): 445-448.

Liu T and Staden JV (2001), Growth rate, water relations and ion accumulation of soybean callus lines differing in salinity tolerance under salinity stress and its subsequent relief, Plant Growth Regulators 34: 277-285. 
Lin CC and Kao CH (2001). Relative importance of $\mathrm{Na}^{+}, \mathrm{Cl}^{-}$ and abscisic acid in $\mathrm{NaCl}$ induced inhibition of root growth of rice seedlings, Plant and Soil 237(1): $135-171$.

Maathuis FJM, Ichida AM, Sanders D and Schroeder JI (1997), Roles of higher plant $\mathrm{K}^{+}$channels, Plant Physiology 114: 1141-1149.

Marschner H (1995), Adaptation of plants to adverse chemical soil conditions In: Mineral Nutrition of Higher Plants, $2^{\text {nd }} E d$. Academic Press, London, UK, pp 596-680.

Misra AN, Sahu SM, Misra M, Singh P, Meera I, Das N, Kar $M$ and Sahu P (1997), Sodium chloride induced changes in leaf growth, and pigment and protein contents in two rice cultivars, Biologia Plantarum 39: $257-262$.

Munns R (2002), Comparative physiology of salt and water stress, Plant Cell and Environment 25(2): 239-250.

Munns R and Tester M (2008), Mechanisms of salinity tolerance, Annual Review of Plant Biology 59: 651-81.

Orcutt MD and Nilsen ET (2000), Salinity stress In: The physiology of plants under stress, John Wiley and Sons, Inc., New York, pp 177-234.

Ottow EA, Brinker M, Teichmann T, Fritz E, Kaiser W, Brosche' M, Kangasjärvi J, Jiang X and Polle A (2005),Populus euphratica displays apoplastic sodium accumulation, osmotic adjustment by decreases in calcium and soluble carbohydrates, and develops leaf succulence under salt stress, Plant Physiology 139: $1762-1772$.

Parida, AK and Das AB (2005), Salt tolerance and salinity effects on plants: A review, Ecotoxicology and Environment 60: 324-349.

Patel AD and Pandey AN (2008), Growth, water status and nutrient accumulation of seedlings of Holoptelea integrifolia (Roxb.) Planch in response to soil salinity, Plant Soil and Environment 54: 367-373.

Sharma N, Gupta NK, Gupta S and Hasegawa H (2005), Effect of $\mathrm{NaCl}$ salinity on photosynthetic rate, transpiration rate, and oxidative stress tolerance in contrasting wheat genotypes,Photosynthetica 43: 609-613.
Sengupta S and Majumder AL (2010), Porteresia coarctata (Roxb.) Tateoka, a wild rice: a potential model for studying salt-stress biology in rice, Plant Cell and Environment 33: 526-542.

Shabala SN (2003), Regulation of potassium transport in leaves:from molecular to tissue level, Annals of Botany 92: $627-634$.

Tester $\mathrm{M}$ and Davenport $\mathrm{R}$ (2003), $\mathrm{Na}^{+}$tolerance and $\mathrm{Na}^{+}$ transport in higher plants, Annals of Botany 91: 503-527.

Trinchant JC, Boscari A, Spennato G, Sype GVD and Rudulier DL (2004), Proline betaine accumulation and metabolism in alfalfa plants under sodium chloride stress, Exploring its compartmentalization in nodules, Plant Physiology 135: 1583-1594.

Velu G and Srivastava GC (2000), Status of sodium-potassium as a basis of salinity tolerance in rice, Indian Journal of Plant Physiology 5(3): 300-302.

Won YJ, Hev MH and Kah HJ (1992), Cation content of salt tolerance and salt susceptible cultivars and its inheritance in rice, Korean Journal of Crop Science 37: $1-8$.

Yadav R, Flowers TJ and Yeo AR (1996), The involvement of the transpirational bypass flow in sodium uptake by high and low sodium transporting lines of rice developed through intravarietal selection, Plant Cell and Environment 19: 329-36.

Yasumoto E, Adachi K, Kato M, Sano H, Sasamoto H, Baba S and Ashihara H (1999), Uptake of inorganic ions and compatible solutes in cultured mangrove cells during salt stress, In Vitro Cellular \& Developmental Biology - Plant 35: 82-85.

Zhou Q, Wang L, Caic X, Wangb D, Huaa X, Qua L, Lina J and Chena $\mathrm{T}$ (2011), Net sodium fluxes change significantly at anatomically distinct root zones of rice (Oryza sativa L.) seedlings, Journal of Plant Physiology 168: 1249-1255. 